\title{
STEAM GASIFICATION OF A BRAZILIAN SUBBITUMINOUS COAL AIMING THE PRODUCTION OF SYNGAS
}

\author{
M. D. DOMENICO ${ }^{1}$, G. C. COLLAZZO ${ }^{2}$, H. J. JOSÉ ${ }^{1}$, R. F. P. M. MOREIRA ${ }^{1}$ \\ ${ }^{1}$ Federal University of Santa Catarina, Department of Chemical Engineering and Food \\ Engineering, Brazil \\ ${ }^{2}$ University of Caxias do Sul, Graduate Program in Engineering and Process Technology, Brazil \\ E-mail contact: michedido@gmail.com
}

\begin{abstract}
The aim of this work was to investigate the gasification of a Brazilian low-rank coal in the temperature range of 1023-1198 K and steam concentration range of $10-40 \%$ in order to evaluate the reaction rate and the product gas composition. Prior to the gasification experiments the raw coal was pyrolysed in a tubular reactor, under $\mathrm{N}_{2}$ atmosphere and at a temperature of $1173 \mathrm{~K}$. The coal and char samples were characterized by several techniques. The gasification experiments were performed in a thermobalance, at atmospheric pressure and isothermal conditions. The reactivity study was conducted in the kinetically controlled regime, three theoretical models were tested to fit the experimental data and the kinetic parameters were determined. It was found that an increase in temperature and steam concentration enhances the reaction rate and also the formation of $\mathrm{H}_{2}, \mathrm{CO}$ and $\mathrm{CO}_{2}$. The gasification kinetics was suitably described by the Shrinking Core Model and an activation energy of 158 $\mathrm{kJ} / \mathrm{mol}$ and a reaction order of 0.78 (related to the steam composition) were found. The $\mathrm{H}_{2} / \mathrm{CO}$ ratio remained nearly constant, about 3.0, in all gasification experiments.
\end{abstract}

\section{INTRODUCTION}

Coal gasification is a promising technology that has been intensively studied over the past several years. This category of thermochemical conversion has vast application possibilities in the energy field, being praised for its efficient, clean and economically competitive attributes (Ochoa et al., 2001; Collot, 2006).

Gasification is defined as the reaction of carbonaceous feedstocks with air, oxygen, steam and/or carbon dioxide aiming the production of syngas $\left(\mathrm{H}_{2}\right.$ and $\left.\mathrm{CO}\right)$, which is suitable for use as a source of energy or as a raw material for the synthesis of chemicals, liquid fuels or other gaseous fuels (Minchener, 2005; Collot, 2006). Producing syngas from coal gasification has attracted major interest mainly due to the generated gas with a $\mathrm{H}_{2} / \mathrm{CO}$ ratio between 1 and 2 . That is the accepted value to produce synthetic fuels by using the Fisher-Tropsh synthesis (via Coal to Liquid process, CTL) (Cao, 2008).

The gasification process can be separated into two steps, referred as pyrolysis (or devolatilization) and gasification, the latter being the rate-controlling step of the overall conversion process. Therefore, it is important to achieve a good understanding of the kinetics of char gasification, since it provides valuable information for the proper design and operation of gasifiers (Ochoa et al., 2001). 
Gasification characteristics of coal are critically dependent on coal type and operating conditions, being the existing database limited. Moreover, information about coals from the South American continent, especially Brazilian coals, is scarce in the literature (Schmal et al., 1982; José, 1989; Collazzo, 2013; Domenico, 2013). Despite the accomplished progress so far, it is still not possible to use data from a particular coal char to predict the behavior of others.

The aim of this work was to investigate the gasification of a Brazilian low-rank coal in a thermobalance, using temperatures between $1023 \mathrm{~K}$ and $1198 \mathrm{~K}$ and steam concentrations between $10 \%$ and $40 \%$. Kinetic parameters were derived and the theoretical model which best represents the gasification behavior of the char coal was determined. The composition of product gas was obtained in order to identify the best operating conditions for the production of syngas.

\section{EXPERIMENTAL WORK}

\subsection{Material}

For this study, it was selected a subbituminous coal extracted from Leão-Butiá Coalfield (CI seam, coordinates $51^{\circ} 55^{\prime} 56.7^{\prime \prime} \mathrm{W}, 30^{\circ} 06^{\prime} 29.3^{\prime \prime}$ ). This is a typical Run of Mine coal (ROM) from the Paraná Basin, located in southern Brazil. As received, the coal sample was grounded, sieved and devolatilised in a quartz tubular reactor. Conditions applied during pyrolysis included: nitrogen flow of $400 \mathrm{ml} / \mathrm{min}$ (purity 99.996\%), heating rate of $190 \mathrm{~K} / \mathrm{min}$ up to the final temperature of $1173 \mathrm{~K}$ and residence time of $5 \mathrm{~min}$. The resulted char was grounded, sieved to a particle size of $<110^{-4} \mathrm{~m}$ and stored under nitrogen atmosphere until gasification tests.

The characteristics of the raw coal and coal char, as determined by several techniques, are summarized in Table 1. Proximate analysis (ash, volatile matter and fixed carbon) was determined according to the standard ASTM E-1131 by thermogravimetry. Ultimate analysis $(\mathrm{C}, \mathrm{H}, \mathrm{N}, \mathrm{S}$ and O) and calorific values were determined according to the standards ASTM D-5373 and ASTM D2015 , respectively. Porous structure analysis was carried out in liquid $\mathrm{N}_{2}$ and at $78 \mathrm{~K}$, and surface areas were calculated using the BET method. Finally, petrography was determined by maceral analysis according to the standard ISO 7403/3-1984 and the coal rank was confirmed by vitrinite reflectance according to the standard ISO 7404/5-1984.

\subsection{Methods}

Reactivity measurements: Thermogravimetric analysis is a frequently used technique for the determination of kinetic parameters of carbonaceous materials. Using TGAs under well-controlled conditions it is possible to produce data that are both applicable and reliable (Shaw et al., 1997). In this work, gasification experiments were carried out in a thermobalance model Dyntherm-HPST, by Rubotherm Company, at atmospheric pressure and isothermal conditions.

The equipment used comprises a gas dosing system and a magnetic suspension balance. The position of the balance allows it to tare and calibrate throughout the experiment, which is extremely important for ensuring measurement accuracy. This feature excludes the effect of buoyancy, and hence, the need of a blank experiment. The operating variables used were in agreement with differential reactor conditions and no internal and external diffusional resistance was found, as experimentally determined in a previous work (DOMENICO, 2013). 
Table 1 - Characterization of the samples.

\begin{tabular}{|c|c|c|}
\hline Sample & Coal & Char \\
\hline \multicolumn{3}{|l|}{ Proximate analysis (wt\% db) } \\
\hline Ash & 45.5 & 56.0 \\
\hline Volatile matter & 24.7 & 5.4 \\
\hline Fixed carbon & 29.8 & 38.6 \\
\hline \multicolumn{3}{|l|}{ Ultimate analysis (wt\% db) } \\
\hline $\mathrm{C}$ & 37.4 & 41.1 \\
\hline $\mathrm{H}$ & 3.8 & 0.5 \\
\hline $\mathrm{N}$ & 0.7 & 0.4 \\
\hline $\mathrm{S}$ & 2.7 & 1.5 \\
\hline $\mathrm{O}($ diff $)$ & 9.9 & 0.5 \\
\hline \multicolumn{3}{|l|}{ Calorific value $(\mathrm{MJ} / \mathrm{kg})$} \\
\hline High & 15.23 & - \\
\hline Low & 14.27 & - \\
\hline \multicolumn{3}{|l|}{ Porous structure } \\
\hline BET surface area $\left(\mathrm{m}^{2} / \mathrm{g}\right)$ & 58.6 & 22.7 \\
\hline Pore volume $\left(\mathrm{cm}^{3} / \mathrm{g}\right)^{\mathrm{i}}$ & 0.066 & 0.008 \\
\hline \multicolumn{3}{|l|}{ Maceral composition (vol\%) } \\
\hline Vitrinite & 32.6 & - \\
\hline Liptinite & 8.40 & - \\
\hline Inertinite & 22.0 & - \\
\hline Mineral matter & 37.0 & - \\
\hline \multicolumn{3}{|l|}{ Vitrinite reflectance (vol\%) } \\
\hline Average value & 0.454 & - \\
\hline Standart deviation & 0.044 & - \\
\hline Number of measurements & 100 & - \\
\hline Rank & Sub. B ${ }^{\text {i1 }}$ & - \\
\hline
\end{tabular}

${ }^{\text {i }}$ Single point adsorption total pore volume. ${ }^{\text {ii }}$ Subbituminous.

Experimental procedure can be summarized as follows: about $0.01 \mathrm{~g}$ of the char sample was placed in an alumina pan. Initially, the system was purged with an argon flow of $100 \mathrm{ml} / \mathrm{N} / \mathrm{min}$ (purity $99.999 \%$ ) for $2 \mathrm{~h}$; then, it was heated at $20 \mathrm{~K} / \mathrm{min}$, under argon atmosphere, up to the reaction temperature (between 1023-1198 K). Subsequently, the inert gas was replaced by an argon/steam mixture (flow rate of $300 \mathrm{ml} / \mathrm{min}$, compositions between 10-40\%). Steam was generated and added to the system by a HPLC pump connected to a stainless steel block heated at $473 \mathrm{~K}$. All external tubes were heated at the same temperature to avoid steam condensation. Gasification reactions were conducted until no more weight loss was observed. The weight changes of the samples were measured at intervals of $10.0 \mathrm{~s}$ with a computerized digital scale. The duplicate for each experiment was performed in order to test the reproducibility of the results. The main syngas products $\left(\mathrm{H}_{2}, \mathrm{CO}, \mathrm{CO}_{2}\right.$ and $\left.\mathrm{CH}_{4}\right)$ were quantified in a gas chromatograph GCTCD/FID coupled with a methanizer (GC-2014 and MTN-1, Shimadzu Company).

Calculations: The fractional carbon conversion $(X)$ was calculated using Equation 1,

$$
X=\left(w_{0}-w_{t}\right) /\left(w_{0}-w_{a s h}\right)
$$


where $w_{0}, w_{t}$ and $w_{\text {ash }}$ represent the initial weight of coal char, the instantaneous weight of coal char and weight of ash, respectively (in $\mathrm{mg}$ ). Considering that the gasification is a single step reaction and the $\mathrm{H}_{2} \mathrm{O}$ partial pressure is constant, the reactivity or reaction rate, $d X / d t(1 / \mathrm{min}$, being $t$ the reaction time), can be expressed by Equation 2 (Jüntgen, 1983; Fermoso et al., 2009),

$$
d X / d t=k(T) f(X)
$$

where the temperature dependent term is the gasification rate coefficient, $(k, 1 / \mathrm{min})$, and $f(X)$ is a structural term, related to the changes of coal char properties during the reaction. $k(T)$ is expressed by means of the Arrhenius relation given by Equation 3,

$$
k=\exp \left(-E_{a} / R T\right)
$$

where $A(1 / \mathrm{min})$ is the frequency factor, $E a(\mathrm{~kJ} / \mathrm{mol})$ is the activation energy, $R$ is the constant of gases $(8.314 \mathrm{~J} / \mathrm{mol} / \mathrm{K})$ and $T(\mathrm{~K})$ is the gasification temperature. $f(X)$ is provided by the $n$ th-order model and in this work, three representative gas-solid models, Volumetric, Shrinking Core and Random Pore, were applied in order to calculate the kinetic parameters (Table 2).

The Volumetric Model (V) is a simplified gas-char heterogeneous model, since it considers that the reaction is similar to a homogeneous reaction and that the surface area decreases with conversion (Wen, 1968; Ishida and Wen, 1971). The Shrinking Core Model (SC) assumes the particle as uniform non-porous grains which shrink during the reaction (Levenspiel, 1967; Wen, 1968; Szekely and Evans, 1970). The reaction order for $\mathrm{V}$ and SC models are 1 and 2/3, respectively. The Random Pore Model (RP) is the only one that contemplates structural changes in the coal char in the gasification process, by using the parameter $\psi$ (Bhatia and Perlmutter, 1980).

Table 2 - Global rate expressions by theoretical Volumetric Model (V), Shrinking Core Model (SC) and Random Pore Model (RP)

\begin{tabular}{lll}
\hline Model & \multicolumn{1}{c}{ Rate expression } & \multicolumn{1}{c}{ Integral form } \\
\hline $\mathrm{V}$ & $\frac{d X}{d t}=k_{V}(1-X)$ & $-\ln (1-X)=k_{V} \cdot t$ \\
$\mathrm{SC}^{\mathrm{ii}}$ & $\frac{d X}{d t}=k_{S C}(1-X)^{2 / 3}$ & $1-(1-X)^{1 / 3}=\frac{k_{S C}}{3} \cdot t$ \\
$\mathrm{RP}$ & $\frac{d X}{d t}=k_{R P}(1-X) \sqrt{[1-\psi \ln (1-X)]}$ & $\frac{2}{\psi}[\sqrt{1-\psi \ln (1-X)}-1]=k_{R P} \cdot t$ \\
\hline
\end{tabular}

${ }^{i 1}$ Expression for spherical particles.

\section{RESULTS AND DISCUSSION}

\subsection{Effect of Temperature and Steam Composition on Carbon Conversion}

The carbon conversion profiles for the gasification experiments of the coal char are shown in Figure 2 and Figure 3. In general, the curves of $X v$ s. $t$ show a similar shape, i.e., they are a straight line up to a conversion of 0.8 , regardless of the experimental conditions (Molina and Mondragón, 1998). As expected, within the same reaction time, the carbon conversion increases with increasing temperature and steam composition. Thus, a higher temperature decreases the total reaction time, e.g., from $758 \mathrm{~min}$ to $53 \mathrm{~min}$, in the temperatures of $1023 \mathrm{~K}$ and $1198 \mathrm{~K}$, 
respectively. Also, a higher steam composition decreases the total reaction time, e.g., from 540 min to $196 \mathrm{~min}$, for steam compositions of $10 \%$ and $40 \%$, respectively. Accordingly, the gasification rate greatly increases (as presented in Table 3), which is a good indication of chemical reaction control.
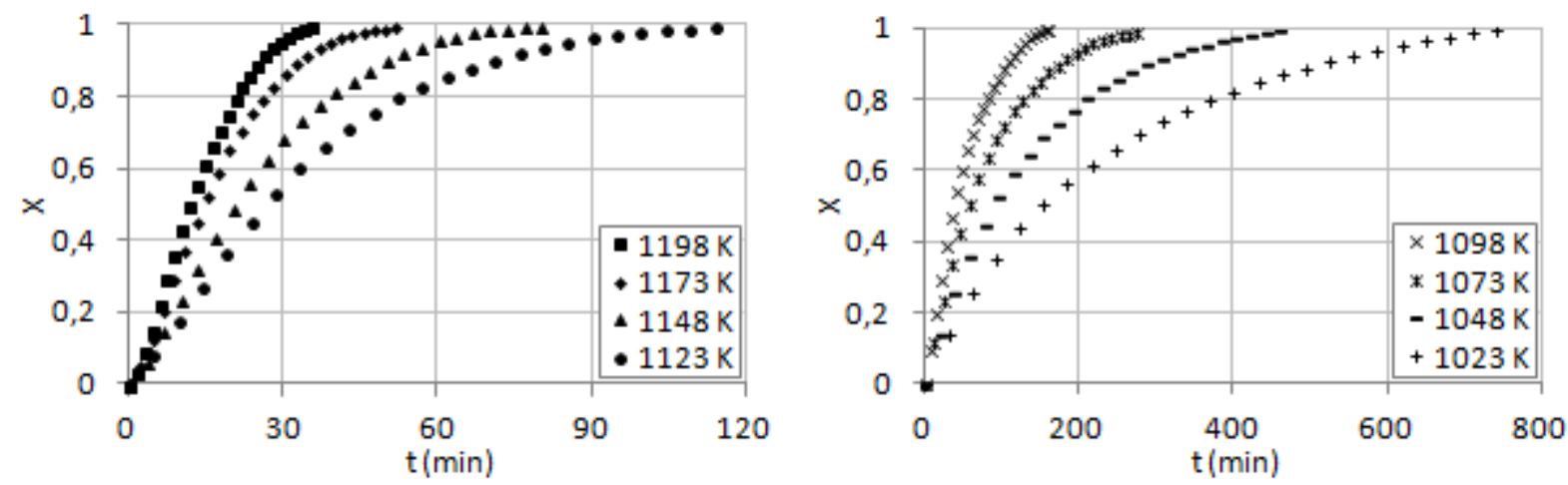

Figure 2 - Carbon conversion versus reaction time at temperatures of $1023 \mathrm{~K}, 1048 \mathrm{~K}, 1073 \mathrm{~K}$, $1098 \mathrm{~K}, 1123 \mathrm{~K}, 1148 \mathrm{~K}, 1173 \mathrm{~K}$ and $1198 \mathrm{~K}$ (steam composition of $30 \%$ ).

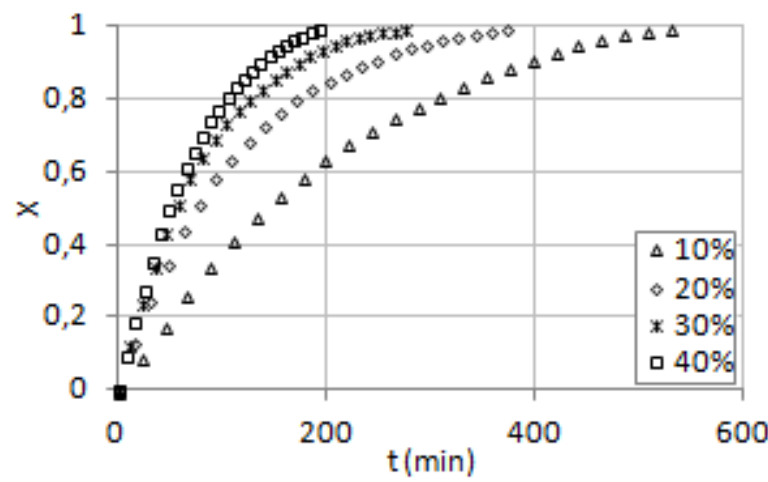

Figure 3 - Carbon conversion versus reaction time for steam compositions of 10\%, 20\%, 30\% and $40 \%$ (temperature of $1073 \mathrm{~K}$ ).

\subsection{Application of Kinetic Models}

The reaction rate constants and the correlation coefficients $\left(\mathrm{R}^{2}\right)$ derived from the fitting of the V, SC and RP models to the experimental data are presented in Table 3. In general, the SC model presented the best fitting, which is a reasonable result, since the gasification is usually classified as an irreversible gas-solid reaction. A similar behavior has been reported in the literature for the gasification of Brazilian coal chars (Schmal et al., 1982; José, 1989; Collazzo, 2013; Domenico, 2013). Although in this work the SC model suitably described the experimental data, it is remarkable that $\mathrm{V}$ and RP models presented a good fitting, mainly in the lower temperature and higher temperature ranges, respectively.

Arrhenius plot for the steam gasification reactivities, found by the fitting of the SC model, resulted in a nearly linear curve $\left(\mathrm{R}^{2}=0,9914\right)$, which confirmed that the reaction occurred in the kinetically controlled regime. The activation energy and frequency factor values were 157.97 $\mathrm{kJ} / \mathrm{mol}$ and $4.84 \cdot 10^{5} 1 / \mathrm{min}$, respectively. 
The results determined from the fitting of SC model to experimental data using steam compositions between $10 \%$ and $40 \%$ are presented in Table 4 . By plotting $\ln \left(k_{S C}\right)$ versus $\ln$ $\left(y_{\mathrm{H} 2 \mathrm{O}}\right)$ it was possible to determine the reaction order related to the steam, which was equal to 0.78 (with a correlation coefficient of 0.9955 ).

Table 3 - Reaction rate constants found by V, SC e RP models (steam composition of 30\%)

\begin{tabular}{c|cc|cc|cc}
\hline Model & \multicolumn{2}{|c|}{$\mathrm{V}$} & \multicolumn{2}{c|}{$\mathrm{SC}$} & \multicolumn{2}{c}{$\mathrm{RP}$} \\
\hline $\mathrm{T}(\mathrm{K})$ & $\mathrm{k}_{\mathrm{V}} \cdot 10^{3}(1 / \mathrm{min})$ & $\mathrm{R}^{2}$ & $\mathrm{k}_{\mathrm{SC}} \cdot 10^{3}(1 / \mathrm{min})$ & $\mathrm{R}^{2}$ & $\mathrm{k}_{\mathrm{RP}} \cdot 10^{3}(1 / \mathrm{min})$ & $\mathrm{R}^{2}$ \\
\hline 1198 & 66.22 & 0.9369 & 55.31 & 0.9704 & 38.02 & 0.9950 \\
1173 & 54.26 & 0.9549 & 45.14 & 0.9829 & 31.39 & 0.9987 \\
1148 & 37.79 & 0.9679 & 31.34 & 0.9905 & 22.17 & 0.9986 \\
1123 & 28.71 & 0.9805 & 23.73 & 0.9970 & 18.05 & 0.9974 \\
1098 & 19.92 & 0.9943 & 16.45 & 0.9972 & 13.41 & 0.9894 \\
1073 & 12.70 & 0.9990 & 10.52 & 0.9940 & 9.03 & 0.9856 \\
1048 & 7.81 & 0.9999 & 6.44 & 0.9859 & 5.53 & 0.9724 \\
1023 & 4.44 & 0.9972 & 3.67 & 0.9721 & 3.15 & 0.9528 \\
\hline
\end{tabular}

Table 4 - Reaction rate constants determined by SC model (temperature of $1073 \mathrm{~K}$ )

\begin{tabular}{c|cc}
\hline Model & \multicolumn{2}{|c}{$\mathrm{SC}$} \\
\hline $\mathrm{y}_{\mathrm{H} 2 \mathrm{O}}$ & $\mathrm{k}_{\mathrm{SC}} 10^{3}(1 / \mathrm{min})$ & $\mathrm{R}^{2}$ \\
\hline 0,1 & 4.27 & 0.9978 \\
0,2 & 7.71 & 0.9888 \\
0,3 & 10.52 & 0.9940 \\
0,4 & 12.43 & 0.9985 \\
\hline
\end{tabular}

\subsection{Product Gas Composition}

The product gas composition ( $\mathrm{mol} \%$ ) as a function of carbon conversion for the gasification experiments at $1073 \mathrm{~K}$ and $1098 \mathrm{~K}$ (steam composition of 30\%) is presented in Figure 4. It can be seen that the concentrations of $\mathrm{H}_{2}, \mathrm{CO}$ and $\mathrm{CO}_{2}$ follow the same trend as observed by the reaction rate and also increase with increasing temperature (the same result was found for the increase in steam composition). The increase of $\mathrm{H}_{2}$ and $\mathrm{CO}$ production is related to the reaction with steam $\left(\mathrm{C}+\mathrm{H}_{2} \mathrm{O} \leftrightarrow \mathrm{CO}+\mathrm{H}_{2}\right)$ and the Boudoard reaction $\left(\mathrm{C}+\mathrm{CO}_{2} \leftrightarrow 2 \mathrm{CO}\right)$ (Fermoso et al., 2008). The $\mathrm{CH}_{4}$ concentration is low and almost not influenced by the gasification temperature.
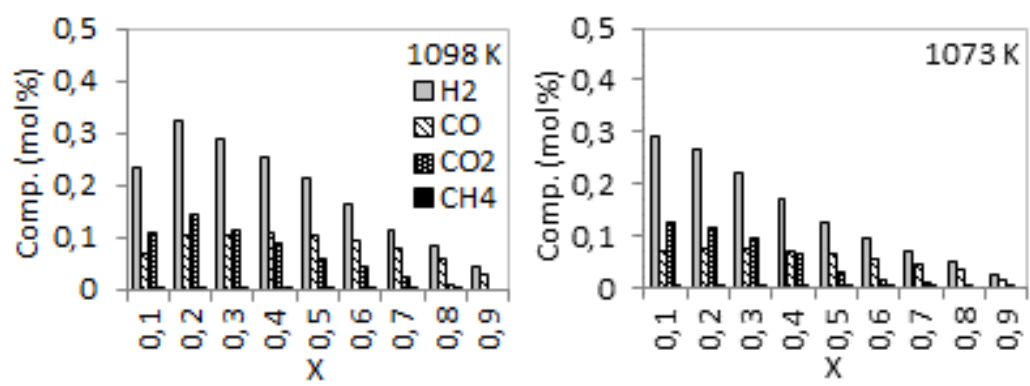

Figure 4 - Concentration of $\mathrm{H}_{2}, \mathrm{CO}, \mathrm{CO}_{2}$ and $\mathrm{CH}_{4}$ versus carbon conversion for gasification experiments at $1073 \mathrm{~K}$ and $1148 \mathrm{~K}$ (steam composition of $30 \%$ ). 
The $\mathrm{H}_{2} / \mathrm{CO}$ ratios for the punctual carbon conversion of $20 \%$ in the gasification experiments at temperatures between $1023 \mathrm{~K}$ and $1148 \mathrm{~K}$ and steam composition of $30 \%$ are presented in Figure 5. As can be seen, the $\mathrm{H}_{2} / \mathrm{CO}$ values remained nearly constant, about 3.0, over the tested temperature and steam concentration ranges, values slightly higher than those required to produce synthetic fuels by the Fisher-Tropsh synthesis.

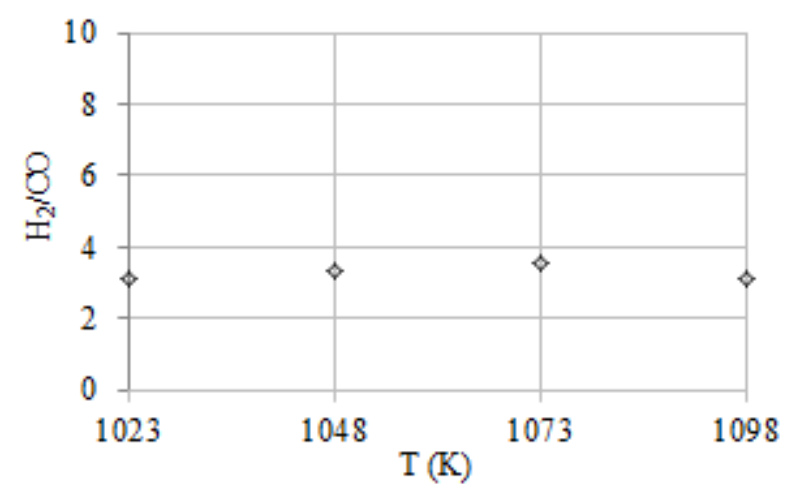

Figure $5-\mathrm{H}_{2} / \mathrm{CO}$ ratio versus temperature for the punctual carbon conversion of $20 \%$ in the gasification experiments at $1023 \mathrm{~K}-1098 \mathrm{~K}$ (steam composition of 30\%).

\section{CONCLUSIONS}

According to the results, it was found that an increment in temperature and steam concentration increases the reaction rate and also the formation of $\mathrm{H}_{2}, \mathrm{CO}$ and $\mathrm{CO}_{2}$ in a great extent. The gasification kinetics was suitably described by the Shrinking Core Model and an activation energy of $158 \mathrm{~kJ} / \mathrm{mol}$ and reaction order of 0.78 (related to the steam composition) were found. The $\mathrm{H}_{2} / \mathrm{CO}$ ratio remained close to 3.0 in all gasification experiments, showing the potential of Brazilian coals in the production of synthetic fuels via Fisher-Tropsh synthesis.

\section{REFERENCES}

ASTM E 1131-03 - American Society for Testing and Material: Standard Test Method for Compositional Analysis by Thermogravimetry. 2004.

ASTM D5373-02 - American Society for Testing and Material: Standard Test Methods for Instrumental Determination of Carbon, Hydrogen, and Nitrogen in Laboratory Samples of Coal. 2002.

ASTM D2015 - American Society for Testing and Material: Standard Test Method for Gross Calorific Value of Coal and Coke by the Adiabatic Bomb Calorimeter. 2000.

BHATIA, S. K.; PERLMUTTER, D. D. A random pore model for fluid-solid reactions: I. Isothermal, kinetic control. AIChe Journal, v. 27, p. 247-54, 1980.

BP Statistical Review of World Energy, June 2013. bp.com/statisticalreview

CAO, Y. Synthesis Gas Production with an Adjustable H2/CO Ratio through the Coal Gasification Process: Effects of Coal Ranks And Methane Addition. Energy \& Fuels, v. 22, p. 1720-1730, 2008.

COLLAZZO, GC. Gaseificação de Carvões Nacionais com Vapor de Água Visando a Produção de Gás de Síntese. Thesis, UFSC, Florianópolis, 2013. 
COLLOT, A-G. Matching gasification technologies to coal properties. International Journal of Coal geology, v. 65, p. 191-212, 2006.

DOMENICO, MD. Gaseificação de Carvão Mineral Brasileiro na Presença de Ortossilicato de Lítio Visando a Produção Aumentada de Hidrogênio. Thesis, UFSC, Florianópolis, 2013.

FERMOSO, J.; ARIAS, B.; PEVIDA, C.; PLAZA, M. G.; RUBIERA, F.; PIS, J.J. Kinetic models comparison for steam gasification of different nature chars. Journal of Thermal Analysis and Calorimetry, v. 91, p. 779-86, 1998.

ISHIDA, M.; WEN, C.Y. Comparison of zone-reation model and unreacted-core shrink model in solid-gas reactions - I (isothermal analysis). Chemical Engineering Science, v. 76, p. 1032-41, 1971.

ISO 7404/3 - International Standard: Methods for the petrographic analysis of bituminous coal and anthracite - Part 3: Method of determining maceral group composition. 1984.

ISO 7404/3 - International Standard: Methods for the petrographic analysis of bituminous coal and anthracite - Part 5: Method of determining microscopically the reflectance of vitrinite. 1984.

JOSÉ, HJ. Zur Reaktivität von Koksen aus Santa Catarina-Steinkohle, Brasilien, bei der Vergasung mit Wasserdampf und Kohlendioxid. Thesis, RWTH Aachen, Germany, 1989.

JÜNTGEN, H. Application of catalysts to coal gasification processes. Incentives and Perspectives. Fuel, v. 62, p. 234-38, 1983.

LEVENSPIEL, O. Chemical Reaction Engineering. 2. Ed. Nova York: John Wiley \& Sons, 1967. 501p.

MINCHENER, A. Coal gasification for advanced power generation. Fuel, v. 84, p. 2222-35, 2005.

MOLINA, A; MONDRAGÓN, F. Reactivity of coal gasification with steam and $\mathrm{CO}_{2}$. Fuel, v. 77, p. 1831-39, 1998.

OCHOA, J; CASSANELLO, MC; BONELLI, PR; CUKIERAN, AL. $\mathrm{CO}_{2}$ gasification of Argentinean coal chars: a kinetic characterization. Fuel Processing Technol., v. 74, p. 161-76, 2001.

SCHMAL, M; MONTEIRO, JLF; CASTELLAN, JL. Kinetics of coal gasification. Ind. Eng. Chem. Process Des. Dev., v. 21, p. 256-66, 1982.

SHAW, KJ; BEAMISH, BB; RODGERS, KA. Thermogravimetric analytical procedures for determining reactivities of chars from New Zealand coals. Thermochimica Acta, v. 302, p. 181-87, 1997.

SZEKELY, Y.J.; EVANS, J.W. A structural model for gas-solid reactions with a moving boundary. Chemical Engineering Science, v. 25, p.1091, 1970.

WEN, C.Y. Noncatalytic heterogeneous solid-fluid reaction models. Industrial and Engineering Chemistry, v. 60, p. 34-54, 1968. 